\title{
Biocontrol of Phytophthora infestans, Fungal Pathogen of Seedling Damping Off Disease in Economic Plant Nursery
}

\author{
B. Loliam, ${ }^{1}$ T. Morinaga, ${ }^{2}$ and S. Chaiyanan' \\ ${ }^{1}$ Department of Microbiology, Faculty of Science, King Mongkut's University of Technology Thonburi, Bangkok 10140, Thailand \\ ${ }^{2}$ Department of Life System Science, Graduate School of Comprehensive, Scientific Research, Prefectural University of Hiroshima, \\ 562 Nanatsuka, Shobara, Hiroshima 727-0023, Japan
}

Correspondence should be addressed to S. Chaiyanan, saipin.cha@kmutt.ac.th

Received 30 May 2012; Accepted 24 July 2012

Academic Editor: Kabkaew Sukontason

Copyright (C) 2012 B. Loliam et al. This is an open access article distributed under the Creative Commons Attribution License, which permits unrestricted use, distribution, and reproduction in any medium, provided the original work is properly cited.

\begin{abstract}
This research aims to control Seedling damping off disease in plants by using antagonistic actinomycetes against the causative fungi. Phytophthora infestans was isolated from the infected tomato plant seedling obtained from an economic plant nursery in Amphoe Pak Chong, Nakhon Ratchasima Province, Thailand. The chitinolytic Streptomyces rubrolavendulae S4, isolated from termite mounds at the grove of Amphoe Si-Sawat, Kanchanaburi Province, Thailand, was proven to be the most effective growth inhibition of fungal pathogens tested on potato dextrose agar. Tomato and chili seedlings that colonized with antagonistic S. rubrolavendulae $S 4$ were grown in P. infestans artificial inoculated peat moss. Percents of noninfested seedling in fungal contaminated peat moss were compared to the controls with uninoculated peat moss. In $P$. infestans contaminated peat moss, the percents of survival of tomato and chili seedling were significantly increased $(P<0.05)$ from 51.42 to 88.57 and 34.10 to 76.71 for the $S$. rubrolavendulae S4 treatment, respectively. The S. rubrolavendulae S4 also showed high efficiency equivalent to fungicide, metalaxyl with no significant difference $(P>0.05)$. It was clearly demonstrated that $S$. rubrolavendulae $S 4$ can prevent the tomato and chili seedling damping off disease in economic plant nurseries.
\end{abstract}

\section{Introduction}

The value of vegetable crops in Thailand was estimated to be around 14,561 million baht in 2009 , including tomato and chili. The plantation of these economic crops is done by using reliable seedling producers. Therefore, the economic plant nursery business has been increasing. Disease management has become a major concern during the production of vegetable plug transplants. The seedling damping off disease causes serious problems in economic plant nurseries. Causative pathogenic fungi of seedling damping off disease in plants were reported to be Pythium spp., Phytophthora sp. [1, 2], Rhizoctonia solani [3], Sclerotium rolfsii [4], and Fusarium oxysporum [5]. Phytophthora infestans is the most infamous species of genus which caused pre- and postemergence damping-off and late blight of potato and tomato. Also, peppers, melons, pumpkins, citruses, strawberries, chestnuts, and forest trees are affected by Phytophthora species such as $P$. cambivora, $P$. hibernalis, $P$. citrophthora, P. kernoviae, P. capsici, P. cactorum, P. drechsleri, and
P. infestans [6-9]. Chemical fungicides are extensively used in current agriculture and also cause environmental pollution. Nowadays, a method of controlling or preventing the disease is by decreasing hazardous chemical fungicides. Biocontrol is used as an alternative method. The microorganism simultaneously grows together with pathogenic fungi and produced enzyme or organic compounds for suppression fungal growth. Biocontrol with microbial fungicides is being investigated in several academic labs. Seedling damping off disease occurred in economic plant nurseries in Amphoe Pak Chong, Nakhon Ratchasima Province. In this study, the major causative fungal pathogens of the seedling damping disease were investigated. The antagonistic chitinolytic Streptomyces against the fungal pathogen was experimented to be used to control the disease in plant nurseries.

\section{Materials and Methods}

2.1. Isolation and Identification of Plant Pathogenic Fungi. The plant samples were obtained from economic plant 


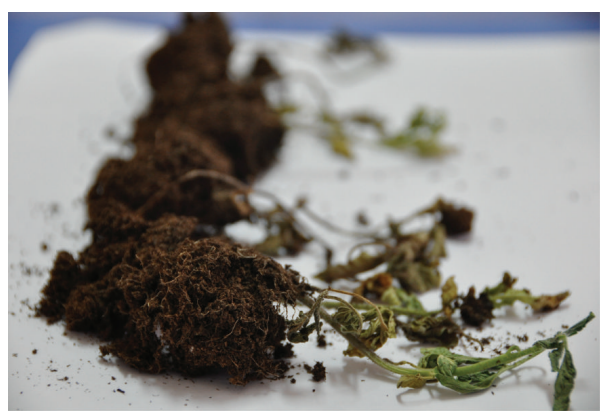

(a)

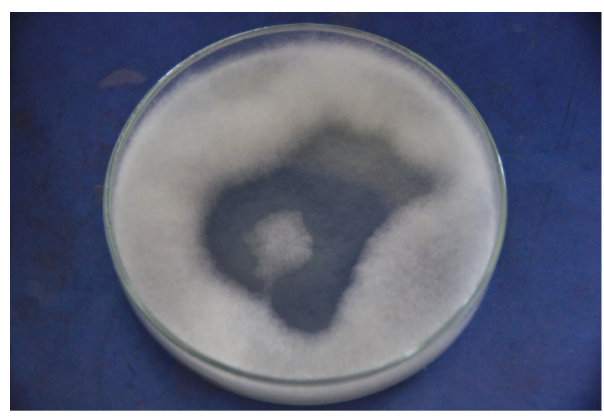

(b)

FIgUre 1: Phytophthora infestans isolated from infected tomato plant seedling (a) and produced white, profusely branching mycelium (b).

nurseries. Roots and stems of tomato seedlings with damping off disease symptoms were washed to remove any excess peat moss. Then, the infested plant parts were surface-sterilized using 5\% v/v hypochlorite for 30 seconds, washed with sterile water, and blot-dried on sterile filter paper. Plant pieces were cut into $0.5 \mathrm{~cm}$ lengths before being placed onto potato dextrose agar (PDA). The fungal mycelium and spores that grew out of the plant tissues were subcultured and purified on another PDA plate. The pathogenic fungi were identified based on colony morphology and by the characteristics of sporangium and oospores.

2.2. Antagonistic Actinomycetes. The chitinolytic actinomycete was isolated from the termite mounds at the grove of Amphoe Si-Sawat, Kanchanaburi Province, Thailand, by using the soil dilution method. The chitinolytic actinomycete was preliminary classified to be Streptomyces sp. based on morphological and physiological characteristics [10]. The chitinolytic actinomycete was found similar to Streptomyces rubrolavendulae based on 16S rRNA analysis. The S. rubrolavendulae S4 was maintained on nutrient agar slants at $30^{\circ} \mathrm{C}$ for $3-5$ days to make the fresh colony before being used in the next experiment.

2.3. Antagonistic Test by Dual Culture Technique. The antifungal activity of the $S$. rubrolavendulae $S 4$ against seedling damping off fungi was tested on V8 agar [11] at $30^{\circ} \mathrm{C}$ using a dual culture technique. The conidia of the S. rubrolavendulae S4 were placed on a V8 agar plate in lines. Then, the plates were incubated at $30^{\circ} \mathrm{C}$ for 5 days to allow growth and sporulation of the S. rubrolavendulae S4 prior to inoculation of an agar plug of the pathogenic fungi at the center of the plate. After incubation for $3-5$ days at $30^{\circ} \mathrm{C}$, the growth inhibition of pathogenic fungi by $S$. rubrolavendulae S4 was investigated. The size of the zone of inhibition developing around the S. rubrolavendulae S4 was a measurement of the antagonistic potential against the pathogen. Only the pathogen was used as a positive control and the experiments were repeated three times with three replications for each experiment. Percentage growth inhibition was determined after 3 days incubation by this formula of Skidmore [12]:
The percentage of inhibition growth $(\%)=\frac{R-r}{R} \times 100$,

where $R$ represents the radius of the control pathogens growth and $r$ the radius of the pathogen's growth towards the bacterial antagonist.

\subsection{Suppression of Seedling Damping Off Fungi under Green-} house Conditions. Peat mosses were sterilized for $15 \mathrm{mins}$ at $121^{\circ} \mathrm{C} 15 \mathrm{lbs} / \mathrm{in}^{2}$ three times at $24 \mathrm{~h}$ intervals and used as a planting material in this study. The agar plugs, taken from the edge of the young colony of pathogenic fungi, were artificial inoculated into steam-pasteurized peat mosses at the rate of 50 agar plugs/250 g. S. rubrolavendulae S4 was cultured in nutrient broth with $1 \% \mathrm{w} / \mathrm{v}$ shrimp shell powder at $30^{\circ} \mathrm{C}$ for 3 days and used for plant protection experiments. The S. rubrolavendulae S4 cell suspension was inoculated into the peat moss at the final concentration of $10^{6} \mathrm{cfu} / \mathrm{g}$. The experiment was a $2 \times 5$ factorial completely randomized design with three replicates. Two kinds of seedling were used: tomato and chili. The 3 sets of 10 seedlings were grown in five types of treated planting material: (1) artificial fungal pathogen infested, (2) artificial fungal pathogen infested but challenged with $S$. rubrolavendulae S4, (3) artificial fungal pathogen infested but treated with fungicide, metalaxyl (Phyto-Q), S. rubrolavendulae S4 inoculated, and (4) uninoculated planting material as control. Percentages of the noninfested seedling were then determined.

\section{Results}

3.1. The Causative Fungal for Damping Off Disease of Seedlings in the Plant Nursery. The major plant pathogenic fungi isolated from the infected tomato plant seedling was identified to be Phytophthora infestans, based on morphology in the form of chlamydospores and sporangia which produce zoospores [13]. This isolate can be grown in PDA and produced white, profusely branching and aseptate mycelium without septum (Figure 1).

The leading edge of mycelia plugs was transferred to petri dishes containing peat moss extract, and then incubated 


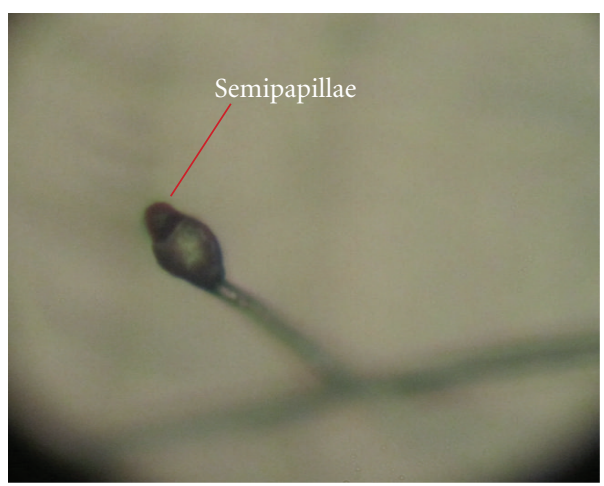

(a)

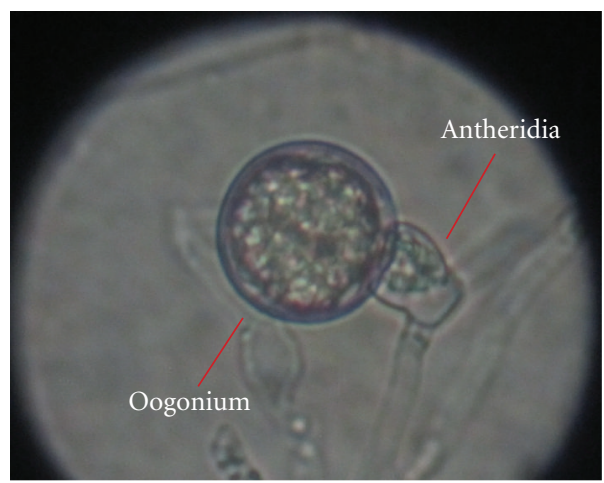

(b)

FIgURE 2: Phytophthora infestans, (a) lemon shape sporangia, (b) amphigynous antheridia of oospores.

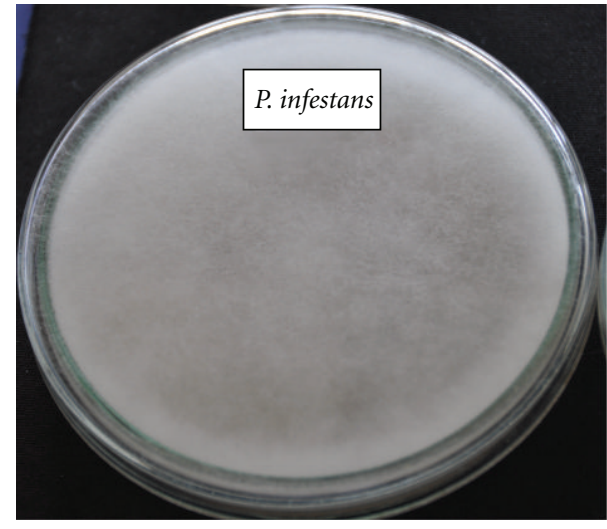

(a)

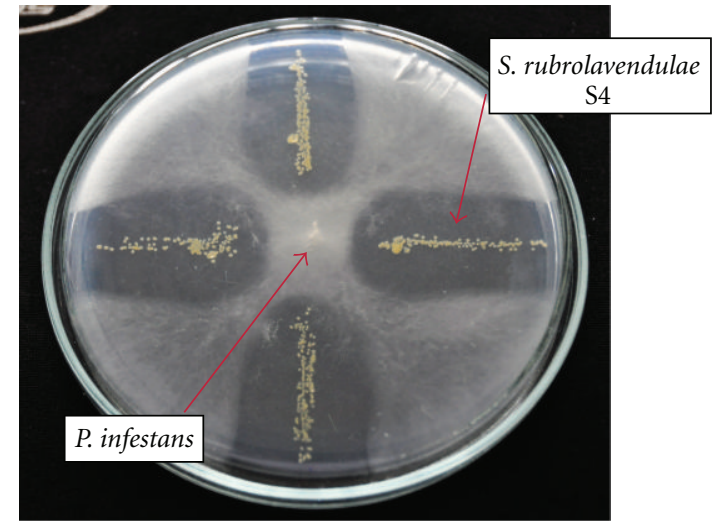

(b)

Figure 3: In vitro interactions between S. rubrolavendulae S4 and Phytophthora infestans on V8 medium. (a) Control plate of Phytophthora infestans; (b) S. rubrolavendulae S4 against Phytophthora infestans.

at room temperature under continuous 40-watt fluorescent illumination for between 1 and 4 days, amphigynous antheridia of oospores. The sporangia in a lemon shape were observed (Figure 2) which are a semipapillae type of sporangia and released zoospores in wet peat moss or water.

3.2. Antagonistic Activity of S. rubrolavendulae S4 against $P$. infestans. The dual culture method that was used to investigate the antagonistic of the S. rubrolavendulae S4 indicated that $S$. rubrolavendulae S4 that was used as antagonistic microorganism for suppression mycelia growth of $P$. infestans on V8 Agar (Figure 3). After being incubated for 3 days at room temperature, the radiuses of $P$. infestans growth on control plate and $P$. infestans growth toward $S$. rubrolavendulae S4 were measured about $4.5 \mathrm{~cm}$ and $0.75 \mathrm{~cm}$, respectively. Moreover, the radial growth of $P$. infestans produced a clear zone around the $S$. rubrolavendulae 44 growth indicating the inhibition of the fungal growth. Therefore, $83.33 \%$ of growth inhibition has clearly demonstrated that $S$. rubrolavendulae S4 exhibited good growth inhibition of the pathogenic fungi, P. infestans.
3.3. Suppression of Tomato and Chili Seedling Damping Off Disease by Antagonistic S. rubrolavendulae S4. The biological suppression of the seedling damping off disease of tomato and chili seedling was performed. S. rubrolavendulae S4 cultured in shrimp shell broth at optimum conditions was inoculated into satirized peat moss. Tomato and chili seedling were grown in peat moss and colonized with antagonistic S. rubrolavendulae S4 and P. infestans. Results from the greenhouse pot experiment demonstrated that S. rubrolavendulae S4 significantly inhibited root rot of tomato and chili seedling caused by $P$. infestans. Percents of noninfested seedling in fungal contaminated peat moss were compared to the controls with uninoculated peat moss. In $P$. infestans contaminated peat moss, the percents of survival of tomato and chili seedling were significantly increased $(P<$ 0.05 ) from 51.42 to 88.57 and 34.10 to 76.71 for the isolate S4 treatment, respectively (Table 1). The S. rubrolavendulae S4 also showed a high efficiency equivalence to fungicide, metalaxyl with no significant difference $(P>0.05)$. These treated plants looked healthy and increased the percentage of healthy plants showing no symptoms of root rot. The $P$. infestans was reisolated from the infested seedling to confirm the effectiveness of the fungal pathogen. 


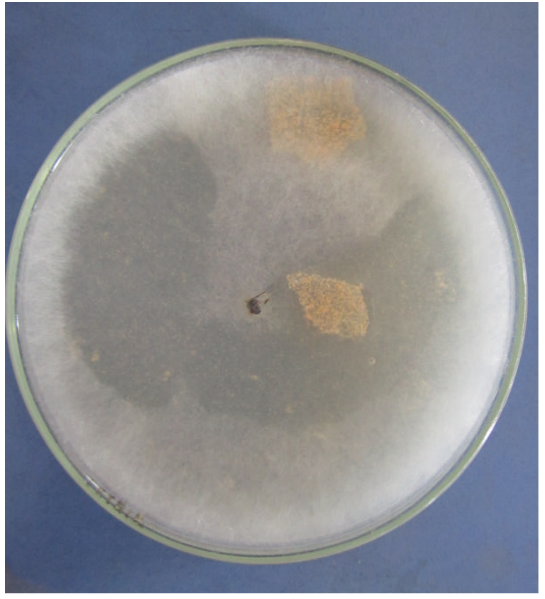

(a)

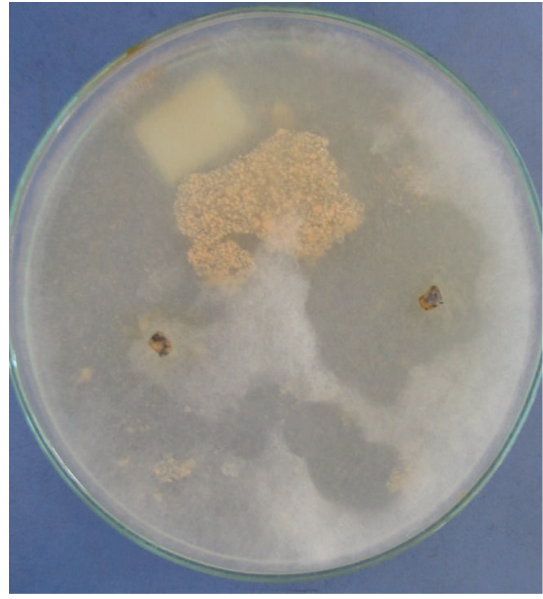

(b)

Figure 4: Phytophthora infestans was observed from peat moss (a) and seeds (b).

TABLE 1: Efficacy of biocontrol, S. rubrolavendulae S4 on suppression of tomato and chili seedling damping off disease caused by Phytophthora infestans under greenhouse conditions.

\begin{tabular}{lcc}
\hline Treatment & Percentage of noninfested tomato seedling & Percentage of noninfested chili seedling \\
\hline Control & $88.56^{\mathrm{b}}$ & $95.71^{\mathrm{c}}$ \\
P. infestans & $51.42^{\mathrm{a}}$ & $34.10^{\mathrm{a}}$ \\
P. infestans + S. rubrolavendulae S4 & $88.57^{\mathrm{b}}$ & $76.71^{\mathrm{b}}$ \\
P. infestans + Phyto-Q & $94.28^{\mathrm{b}}$ & $79.99^{\mathrm{b}}$ \\
S. rubrolavendulae S4 & $87.14^{\mathrm{b}}$ & $90.29^{\mathrm{bc}}$
\end{tabular}

$\overline{\mathrm{a}, \mathrm{b}, \mathrm{c}}$ Means within a column with the same letter were not significantly different $(P>0.05)$.

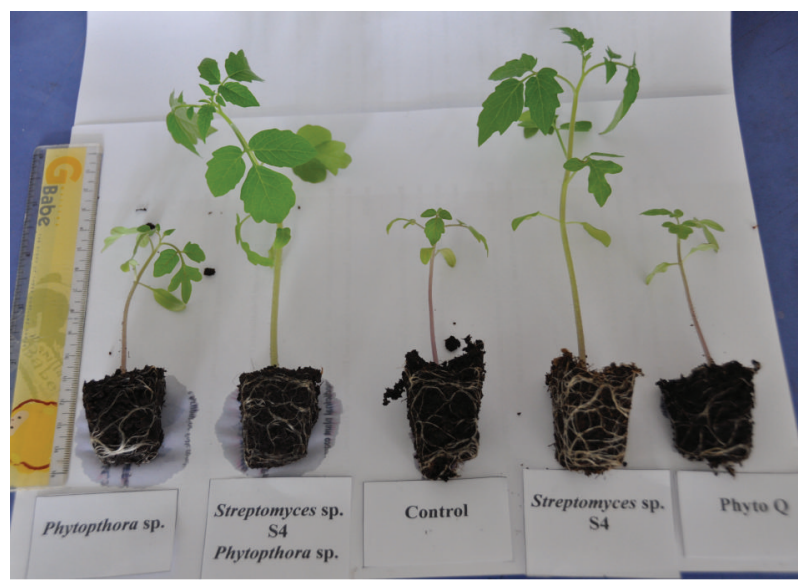

FIGURE 5: The healthy tomato seedlings grown in peat moss inoculated with Phytophthora infestans and S. rubrolavendulae S4 in different treatments.

\section{Discussion}

The plant pathogenic fungi, Phytophthora infestans, was isolated from the infected tomato plant seedling in the economic plant nursery. Phytophthora often called water mold can be grown in wet soil and produced white, profusely branching, aseptate mycelium, sporangia, and oospores. This Phytophthora can spread widely with zoospores and oospores which are produced in sporangium and oogonium, respectively [14].

In sexual spore type, oospores were produced when antheridia was attached to oogonium. Moreover, asexual spore types of $P$. infestans are chlamydospores and sporangia were used as a survival structure. The zoospores were contained in a lemon shape of sporangium (Figure 2(a)).

In the plant fields, greenhouses, and nurseries, chemical fungicides were used for disease management. Metalaxyl and fosetyl-A1 are suggested chemical fungicides to be used against Phytophthora species which are dangerous for the environment [15-18]. Therefore, the biological control was applied for disease management that will be safer for health and the environment. Control of Phytophthora root rot was achieved by infesting peat moss with Streptomyces at the time of planting under greenhouse conditions.

The frequency of healthy plants increased significantly for the susceptible variety, and the average disease severity index decreased significantly for both the resistant and susceptible varieties tested. It was clearly demonstrated that isolate S4 could prevent the tomato and chili seedling damping off disease in the economic plant nursery. In recent studies, the Trichoderma harzianum, Bacillus subtilis, Pseudomonas fluorescens, and Streptomyces species were reported as commercial biocontrol agents for controlling Phytophthora species (BCA) [2, 19-25]. The mechanisms of parasitism, competition, antibiotic, and enzyme were performed in different antagonistic microorganisms. 
The extracellular cell wall degrading enzymes including chitinases, cellulases, amylases, and 1,3- $\beta$-glucanases are found in the genus Streptomyces [26-28]. The high chitinases and cellulases activities were produced by $S$. rubrolavendulae S4.

The 51.42 and 34.10 percentage of survival of tomato and chili seedling were observed in pots containing $P$. infestans, respectively (Table 1 ). After $3-5$ days of cultivation in pots, the tomato and chili appeared to contain seedling damping off disease. A soften, decayed, weakened, and die seedling were expressed in pregerminated and postgerminated chili and tomato seeds. Then, peat mosses or seeds were transferred onto PDA plates and cultured at room temperature for 3 days (Figure 4 ). After that the similarity characteristics to Phytophthora infestans were observed from that plate. An aseptate mycelium, lemon shape of sporangium, and oogonium were observed under a light microscope (10X). The results indicated that the expression of damping off disease in chili and tomato seedlings is caused by Phytophthora infestans. After 50 days of cultivation, the healthy tomato and chili transplants were performed in treatments with added $S$. rubrolavendulae S4. These transplants showed higher height and weight than other treatments (data not show) (Figure 5). The bioactive natural compounds and plant hormones can be produced from several Streptomyces species and affect the host plant as plant growth promotion bacteria $[29,30]$. The results clearly demonstrated that seedling damping off disease of tomato and chili in economic plant nurseries can be controlled by S. rubrolavendulae S4.

\section{Conclusion}

The chitinolytic S. rubrolavendulae S4 had a strongantagonistic activity against Phytophthora infestans, isolated from the infected tomato plant seedlings. Therefore, $S$. rubrolavendulae S4 can be used as a good biocontrol for seedling damping off disease in economic plant nurseries. In $P$. infestans contaminated peat moss, the biocontrol increased the percentage of surviving tomato and chili seedling from 51.42 to 88.57 and 34.10 to 76.71 , respectively. The mass cell production of $S$. rubrolavendulae S4 in an appropriate medium will be conducted as future work.

\section{Acknowledgment}

The authors would like to thank Green and Clean Vegetables Limited, the economic plant nursery in Amphoe Pak Chong, Nakhon Rachasima Province, for supporting the plant samples.

\section{References}

[1] G. J. Joo, "Production of an anti-fungal substance for biological control of Phytophthora capsici causing phytophthora blight in red-peppers by Streptomyces halstedii," Biotechnology Letters, vol. 27, no. 3, pp. 201-205, 2005.

[2] K. Xiao, L. L. Kinkel, and D. A. Samac, "Biological control of Phytophthora root rots on alfalfa and soybean with Streptomyces," Biological Control, vol. 23, no. 3, pp. 285-295, 2002.
[3] O. Asaka and M. Shoda, "Biocontrol of Rhizoctonia solani damping-off of tomato with Bacillus subtilis RB14," Applied and Environmental Microbiology, vol. 62, no. 11, pp. 40814085, 1996.

[4] R. Errakhi, F. Bouteau, A. Lebrihi, and M. Barakate, "Evidences of biological control capacities of Streptomyces spp. against Sclerotium rolfsii responsible for damping-off disease in sugar beet (Beta vulgaris L.)," World Journal of Microbiology and Biotechnology, vol. 23, no. 11, pp. 1503-1509, 2007.

[5] K. Getha and S. Vikineswary, "Antagonistic effects of Streptomyces violaceusniger strain G10 on Fusarium oxysporum f.sp. cubense race 4: indirect evidence for the role of antibiosis in the antagonistic process," Journal of Industrial Microbiology and Biotechnology, vol. 28, no. 6, pp. 303-310, 2002.

[6] C. M. Brasier, P. A. Beales, S. A. Kirk, S. Denman, and J. Rose, "Phytophthora kernoviae sp. nov., an invasive pathogen causing bleeding stem lesions on forest trees and foliar necrosis of ornamentals in the UK," Mycological Research, vol. 109, no. 8, pp. 853-859, 2005.

[7] D. M. Rizzo, M. Garbelotto, J. M. Davidson, G. W. Slaughter, and S. T. Koike, "Phytophthora ramorum as the cause of extensive mortality of Quercus spp. and Lithocarpus densiflorus in California," Plant Disease, vol. 86, no. 3, pp. 205-214, 2002.

[8] G. E. S. J. Hardy, S. Barrett, and B. L. Shearer, "The future of phosphite as a fungicide to control the soilborne plant pathogen Phytophthora cinnamomi in natural ecosystems," Australasian Plant Pathology, vol. 30, no. 2, pp. 133-139, 2001.

[9] S. Z. Islam, M. Babadoost, K. N. Lambert, A. Ndeme, and H. M. Fouly, "Characterization of Phytophthora capsici isolates from processing pumpkin in Illinois," Plant Disease, vol. 89, no. 2, pp. 191-197, 2005.

[10] E. B. Shirling and D. Gottlieb, "Methods for characterization of Streptomyces species," International Journal of Systematic Bacteriology, vol. 16, pp. 313-340, 1966.

[11] P. M. Miller, "V8 juice agar as a general-purpose medium for fungi and bacteria," Phytopathology, vol. 45, pp. 461-462, 1955.

[12] A. M. Skidmoreand and C. M. Dickinson, "Colony interactions and hyphal interferences between Septoria nodorum and phylloplane Fungi," Transactions of the British Mycological Society, vol. 66, pp. 57-64, 1976.

[13] H. S. Judelson and F. A. Blanco, "The spores of Phytophthora: weapons of the plant destroyer," Nature Reviews Microbiology, vol. 3, no. 1, pp. 47-58, 2005.

[14] D. Andrivon, C. Beasse, and C. Laurent, "Characterization of isolates of Phytophthora infestans collected in northwestern France from 1988 to 1992," Plant Pathology, vol. 43, no. 3, pp. 471-478, 1994.

[15] L. V. Edington, K. L. Khew, and G. I. Barron, "Fungitoxic spectrum of benzimidazole compounds," Phytopathology, vol. 61 , no. 1, pp. 42-44, 1971.

[16] R. M. Davis, "Effectiveness of fosetyl-A1 against Phytophthoraparasitica on tomato," Plant Disease, vol. 73, pp. 215-217, 1989.

[17] S. P. Flett, W. J. Ashcroft, P. H. Jerie, and P. A. Taylor, "Control of Phytophthora root rot in processing tomatoes by metalaxyl and fosetyl-Al," Australian Journal of Experimental Agriculture, vol. 31, pp. 279-283, 1991.

[18] N. Ioannou and R. G. Grogan, "Control of Phytophthora root rot of processing tomato with ethazol and metalaxyl," Plant Disease, vol. 68, pp. 429-435, 1984. 
[19] H. Lozoya-Saldaña, M. H. Coyote-Palma, R. Ferrera-Cerrato, and M. E. Lara-Hernández, "Microbial antagonism against Phytophthora infestans (Mont) de Bary," Agrociencia, vol. 40, no. 4, pp. 491-499, 2006.

[20] H. Bae, D. P. Roberts, H. S. Lim et al., "Endophytic Trichoderma isolates from tropical environments delay disease onset and induce resistance against Phytophthora capsici in hot pepper using multiple mechanisms," Molecular Plant-Microbe Interactions, vol. 24, no. 3, pp. 336-351, 2011.

[21] M. Ezziyyani, S. C. Perez, A. A. Sid, R. M. Emilia, and C. M. Emilia, "Trichoderma harzianum as biofungicide for biocontrol of Phytophthora capsici in pepper plants (Capsicum annuum L)," Annals of Biology, vol. 26, pp. 35-45, 2004.

[22] Z. Yan, M. S. Reddy, C. M. Ryu, J. A. McInroy, M. Wilson, and J. W. Kloepper, "Induced systemic protection against tomato late blight elicited by plant growth-promoting rhizobacteria," Phytopathology, vol. 92, no. 12, pp. 1329-1333, 2002.

[23] Z. Q. Jiang, Y. H. Guo, S. M. Li, H. Y. Qi, and J. H. Guo, "Evaluation of biocontrol efficiency of different Bacillus preparations and field application methods against Phytophthora blight of bell pepper," Biological Control, vol. 36, no. 2, pp. 216-223, 2006.

[24] E. T. Lee, S. K. Lim, D. H. Nam, Y. H. Khang, and S. D. Kim, "Pyoverdin2112 of Pseudomonas fluorescens 2112 inhibits Phytophthora capsici, a red-pepper blight-causing fungus," Journal of Microbiology and Biotechnology, vol. 13, no. 3, pp. 415-421, 2003.

[25] M. Fialho de Oliveira, M. Germano da Silva, and S. T. Van Der Sand, "Anti-phytopathogen potential of endophytic actinobacteria isolated from tomato plants (Lycopersicon esculentum) in southern Brazil, and characterization of Streptomyces sp. R18(6), a potential biocontrol agent," Research in Microbiology, vol. 161, no. 7, pp. 565-572, 2010.

[26] T. Taechowisan, C. Lu, Y. Shen, and S. Lumyong, "Secondary metabolites from endophytic Streptomyces aureofaciens CMUAc130 and their antifungal activity," Microbiology, vol. 151, no. 5, pp. 1691-1695, 2005.

[27] G. Mukherjee and S. K. Sen, "Purification, characterization, and antifungal activity of chitinase from Streptomyces venezuelae P10," Current Microbiology, vol. 53, no. 4, pp. 265-269, 2006.

[28] A. Anitha and M. Rabeeth, "Degradation of fungal cell walls of phytopathogenic fungi by lytic enzyme of Streptomyces griseus," African Journal of Plant Science, vol. 4, pp. 61-66, 2010.

[29] Y. Igarashi, M. Ogawa, Y. Sato et al., "Fistupyrone, a novel inhibitor of the infection of Chinese cabbage by Alternaria brassicicola, from streptomyces sp. TP-A-0569," Journal of Antibiotics, vol. 53, no. 10, pp. 1117-1122, 2000.

[30] R. K. Tokala, J. L. Strap, C. M. Jung et al., "Novel plantmicrobe rhizosphere interaction involving Streptomyces lydicus WYEC108 and the pea plant (Pisum sativum)," Applied and Environmental Microbiology, vol. 68, no. 5, pp. 2161-2171, 2002. 

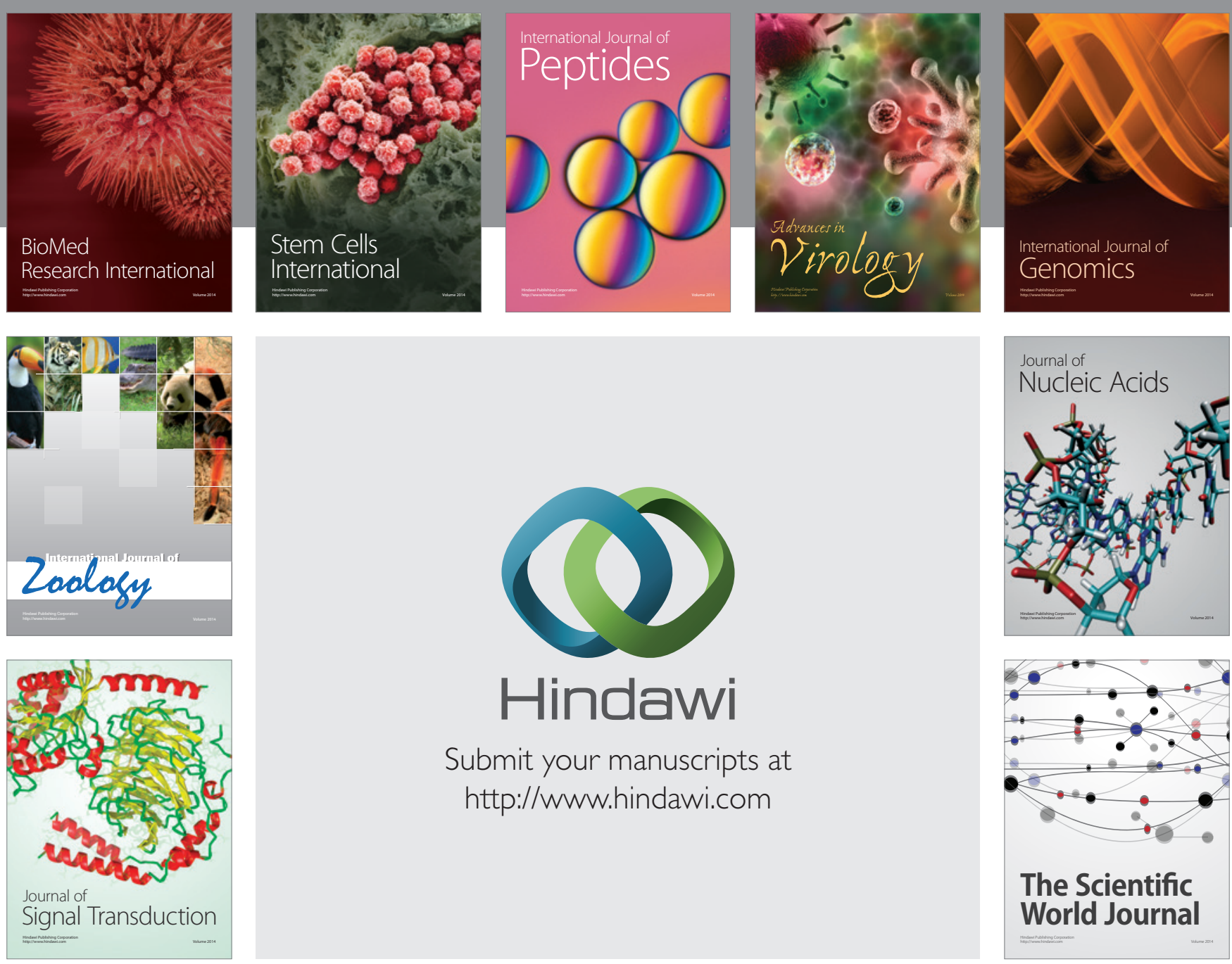

Submit your manuscripts at

http://www.hindawi.com
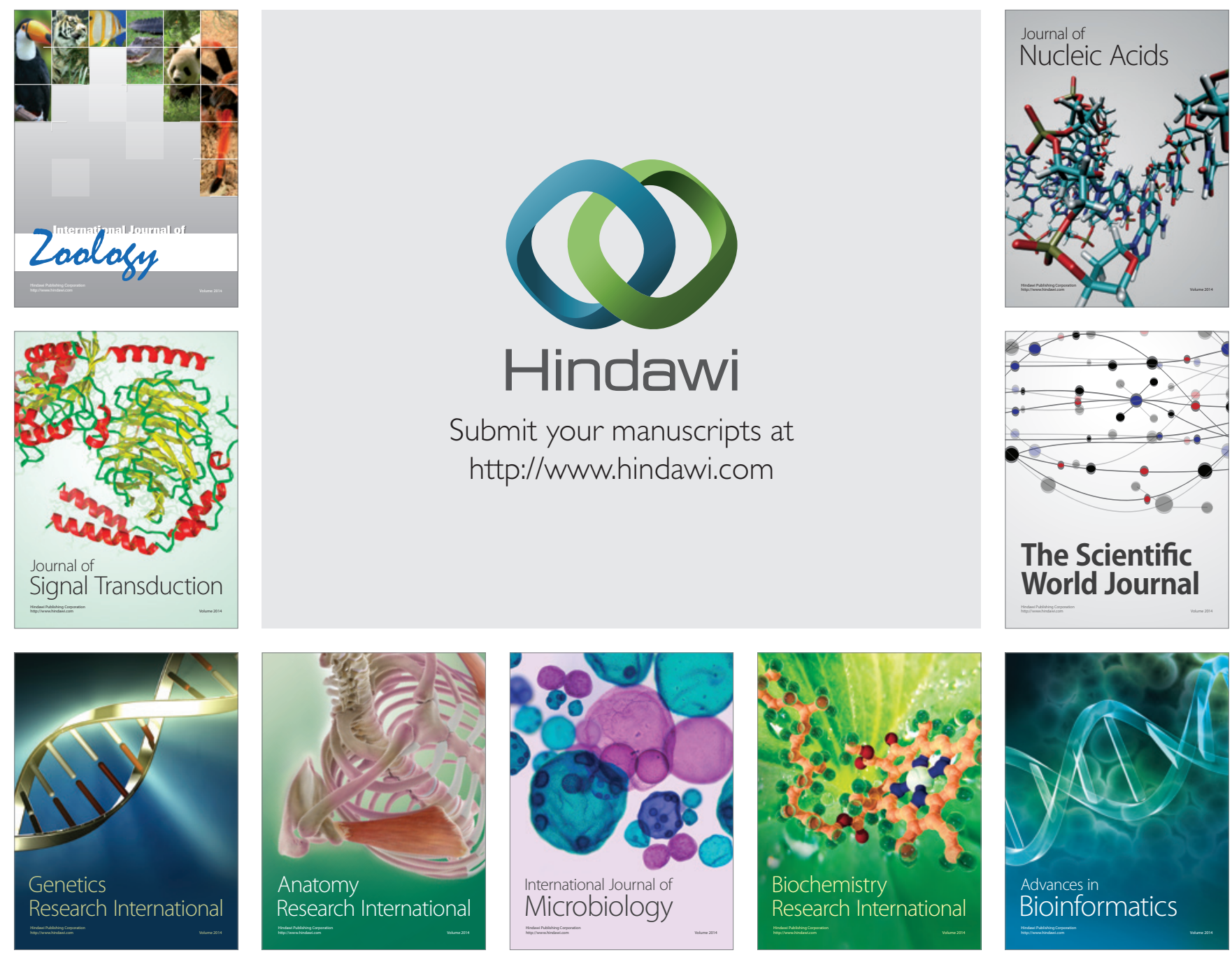

The Scientific World Journal
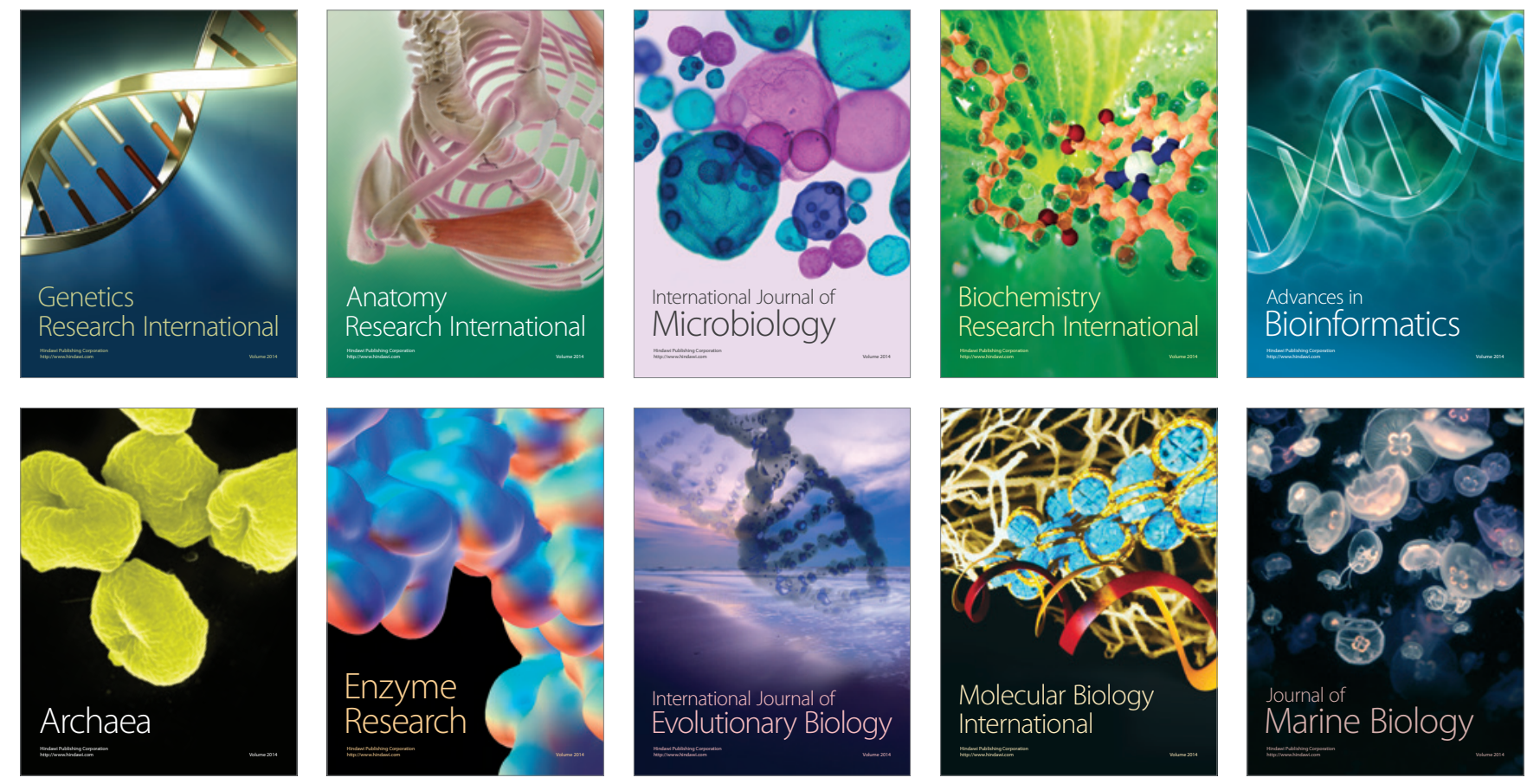